\title{
Opioid peptides and opiate alkaloids in immunoregulatory processes
}

\author{
George B. Stefano, Richard M. Kream
}

Neuroscience Research Institute, State University of New York, College at Old Westbury, Old Westbury, USA

Submitted: 13 May 2010

Accepted: 11 June 2010

Arch Med Sci 2010; 6, 3: 456-460

DOI: 10.5114/aoms.2010.14271

Copyright ( 2010 Termedia \& Banach
Corresponding author:

George B. Stefano

Neuroscience Research

Institute

State University of New York

Old Westbury

NY 11568, USA

Phone: 516-876-2732

Fax: 516-876-2727

E-mail: gstefano@sunynri.org

\begin{abstract}
Among the various non-neuronal cell types known to express and utilize neuropeptides, those of the immune system have received much attention in recent years. In particular, comparative studies in vertebrates and invertebrates have shown that endogenous opioid peptides are engaged in receptor mediated autoregulatory immune and neuroendocrine processes. The majority of these immune processes are stimulatory, as determined by their effects on conformational changes indicative of immunocyte activation, cellular motility, and phagocytosis. Endogenous opioid peptides form an effective network of messenger molecules in cooperation with cytokines, opiate alkaloids, and certain regulatory enzymes (neutral endopeptidase 24.11). Peptide-mediated immunostimulatory effects observed in this system are operationally counteracted by the inhibitory effects of morphine and related opiates. Opioid/opiate signaling processes are mediated by several types of receptors with different degrees of selectivity. Among them the recently identified, opioid insensitive $\mu_{3}$ receptor deserves attention on account of its specificity for opiate alkaloids.
\end{abstract}

Key words: opioid peptides, morphine, leukocytes, immunoregulation, invertebrate immune cells, G protein, neutral endopeptidase.

\section{Introduction}

There is a growing realization in biological sciences that neuropeptides, formerly thought to be produced by a select group of neurons, are found in a variety of non-neuronal cells. Comparative studies in vertebrates and invertebrates [1-4] have highlighted the biological importance of immunoactive cells which make use of neuropeptides for autoregulatory control as well as the bidirection exchange of information between the immune system and the neuroendocrine system. Along with cytokines, long considered to be the primary messenger molecules of the immune system, endogenous opioid peptides form an effective network of communication. Previous studies demonstrated the presence of opioid peptides and opiate alkaloids in both invertebrate and vertebrate nervous and immune systems along with highly selective types of opioid receptors [5-9].

\section{Functional aspects}

Biological activities associated with proinflammatory processes that have been analyzed in detail in higher invertebrates as well as vertebrates 
include cellular adherence, locomotory activity and conformational changes of immunocompetent cells (see Scharrer and Stefano, 1994). Adherence of mammalian neutrophils and invertebrate immunocytes is enhanced by opioid neuropeptides (see $[10,11])$. In human neutrophils substance P (10$11 \mathrm{M})$ modulates the expression of two cell-surface adhesion molecules, Mo 1 and LAM-1 [12]. Polymorphonuclear leukocytes (PMN), lymphocytes, and monocytes as well as invertebrate immunocytes in addition to random movements (chemokinesis), show migratory behavior directed toward sites of inflammation or antigenic challenge (chemotaxis). In an vitro study by Heagy [13-18] and colleagues, T-lymphocytes exhibited chemotaxis in the presence of a concentration gradient of Metenkephalin or b-endorphin. Synthetic enkephalin analogs, including DADLE (D-Ala2-D-Leu5enkephalin), DPDPE (D-Pen2-D-Pen5-enkephalin), and DAG0 (D-Ala2-MePhe4Gly5-enkephalin) stimulated the T-cells to a lesser extent, a finding that will be discussed below. In vitro tests with immunocytes of Mytilus and Leucophaea showed chemotactic movements and the formation of large cellular clumps after opioid peptide exposure along with the same poor reaction to DADLE (see [19-21]).

Furthermore, changes in the activity of human and invertebrate immunocytes are preceded by characteristic conformational alterations. Prior to the onset of locomotory behavior, stimulated by opioid peptides, the following signs indicative of cellular activation are observed. Mammalian and invertebrate cells in the inactive condition are more or less rounded, upon activation show an increase in cellular size and surface area and/or the formation of pseudopodia. D'Ala2-Met5-enkephalinamide (DAMA) is most effective in inducing these changes. DADLE, the compound most closely related to DAMA, is not as potent in mammalian and invertebrate immunocytes (see [19-25]). The distinctly lower effectiveness of DADLE in both human and invertebrate immune reactions is in contrast to the situation in the mammalian nervous system where no discrepancy in the binding potency of Metenkephalin and Leu-enkephalin has been observed (see [10]). Taken together, these studies demonstrate that opioid peptides exhibit, in general, immunostimulatory actions.

\section{Immunocyte opioid receptors}

Deltorphin I, a naturally occurring opioid peptide isolated from amphibian skin, has the ability to modulate both human and invertebrate immunoregulatory activities in a manner quite similar to Met-enkephalin [26]. Its binding and pharmacological studies also have provided evidence for a special subtype of $\delta$ opioid receptor $\delta_{2}$, sensitive to naltrindole antagonism [3, 4, 10, 27], on human and invertebrate immune cells [26]. The results obtained with deltorphin I support the view that the special role played by endogenous Metenkephalin in immunobiological activities of vertebrates and invertebrates is mediated by a special subtype of delta opioid receptor, $\delta_{2}$. It is also of interest to note that both the invertebrate immunocytes and human granulocytes thus have a $\delta_{1}$ and $\delta_{2}$ receptor.

\section{Opiate alkaloids}

While opiate alkaloids, e.g., morphine, are not opioid peptides they do deserve special attention within the context of this review for several reasons. First, unlike antinociceptive mechanisms, opiate alkaloids and opioid peptides initiate different immunocyte behaviors [10]. As noted above, opioid peptides may be generally regarded as immunocyte stimulatory and/or activating ligands whereas morphine, noted first by Wybran et al. [28], is inhibitory. Secondly, confusion exists in the scientific literature as to the proper terminology for these ligands, e.g., opioid alkaloid and opiate peptide. Thirdly a novel opiate alkaloid and opioid peptide insensitive receptor, namely $\mu_{3}$, has been demonstrated which does not recognize $\mu$-opioid ligands [6, 29-37]. Lastly, opiate alkaloids appear to be naturally occurring substances found both in mammals and invertebrates (see [6-10, 29, 32, 33, 35-42]).

The above reports demonstrate that morphine and codeine substances were found in the pedal ganglia, hemolymph and mantle tissues of the mollusc Mytilus edulis [38, 39]. The pharmacological activities of the endogenous morphine material resemble those of authentic morphine. Both substances were found to counteract, in a dose dependent manner, the stimulatory effect of tumor necrosis factor (TNF)- $\alpha$ or interleukin (IL)- $1 \alpha$ on human monocytes and Mytilus immunocytes. The immunosuppressive effect of this opiate material expresses itself in a lowering of chemotactic activity, cellular velocity and adherence as well as making active immunocytes inactive (rounded). These pharmacological effects of morphine on immunocytes are consistent with those actions attributed to opiates reported in the literature (see [10]). Indeed, it has been surmised that morphinergic transmission may regulate the down regulation of immune activation (see [6-8, 31, 32, 35-37, 40, 41, 43-49]).

Along with the opiate substances found in animal tissues came the recent discovery of a specific high-affinity and novel receptor site $\left(\mu_{3}\right)$ for opiate alkaloids on human monocytes as well as Mytilus immunocytes [29, 30, 50]. A variety of opioid peptides, tested by two methods, were found to be ineffective in displacing specifically bound 
3-dihydromorphine. By contrast, the opiate alkaloid $\mathrm{m}$ ligands were potent and $\kappa$ ligands dynorphin 1-17 and ethyl-keto-cyclazocine (EKC) were weak. Based on this novel displacement information we assigned this opioid peptide insensitive and opiate alkaloid sensitive site the name $\mu_{3}$ [29]. Studies demonstrate that human granulocytes also contain the $\mu_{3}$ subtype opiate receptor mediating inhibition by morphine and other opiates of cytokine-induced activation and chemotaxis [51-53]. Furthermore, in the presence of $\mathrm{NaCl}(50 \mathrm{mM})$ plus the GTP analog GppNHp $(100 \mu \mathrm{M})$, there was a significant decrease in specific high-affinity binding of the agonist ligand ${ }^{3} \mathrm{H}$-morphine. The influence of the GTP analog GppNHp on binding indicated that the granulocyte receptor was linked to a $G$ protein [52]. The discovery of this receptor site mediating opiate effects was first found in an invertebrate and then in man, again demonstrating the value of the comparative approach [54].

It is important to note that the cloning of delta, $\mathrm{mu}$ and $\kappa$ receptors has now been accomplished [55-58]. As a result of these and other studies now published it will be possible to study individual receptors regarding their effector coupling, pharmacological characteristics, regulation of expression as well as their regional distributions. Important information will also become available regarding their evolvement.

\section{Biomedical significance}

The biomedical importance of a well balanced immunoregulatory system is illustrated by the consequence of interference with its normal operation (see [27, 59]). Recent studies have shown that immunosuppression effected by neuropeptides may determine the course of certain diseases caused by parasites or viral infection [60-66]. There is experimental evidence supporting the concept that in schistosomiasis the parasite escapes detection and an effective immune reaction in the host by using the same signal molecules operating in the human immune and autoimmunoregulatory system. The release of ACTH by the adult parasite, and its conversion to a-MSH by NEP on human PMNs, inactivates specific defense cells and thus interferes with proper surveillance. Furthermore, the human immunodeficiency virus appears to have the ability to stimulate the production of ACTH by human immune cells [65] thus creating a scenario similar to that described for the parasitic worm. It is becoming quite clear that these peptides play important immunoregulatory roles, actions that include neuroimmune as well as autoimmunoregulatory mechanisms.

Furthermore, recent work has elucidated the enzymes and other regulatory phenomena involved with morphine biosynthesis and their regulation [31, 34-40, 44, 45, 67-73]. It is important to note that substances of abuse impact this system and appear to work, in part, by releasing morphine from cells that make it [7, 31, 34-36, 74-76].

\section{Conclusions}

I surmise that we are just scratching the surface of the involvement of neuropeptides and opiate alkaloids in immune and vascular regulation. This review has mainly emphasized the roles of opioid and related peptides, clearly leaving out many other types of peptidergic signaling compounds. For the most part, it is the opioid/opiate "story" that has emerged in recent years. Thus, we will undoubtedly look forward to the activities and presence of other peptidergic signaling molecules being used both in autoimmunoregulation and neuroimmunoregulation. Given the presence of many of these signaling molecules in neuroendocrine structures the field of neurosecretion will grow to include, if it hasn't already done so, neuroimmunology.

\section{References}

1. Hughes TK, Chin R. Interactions of neuropeptides and cytokines. In: Scharrer B, Smith EM, Stefano GB (eds). Neuropeptides and Immunoregulation. Berlin: SpringerVerlag 1994; 101-19.

2. Scharrer B, Smith EM, Stefano GB. Neuropeptides in neuroimmunology. Heidelberg, Springer 1994.

3. Stefano GB. Pharmacological and binding evidence for opioid receptors on vertebrate and invertebrate blood cells. In: Scharrer B, Smith EM, Stefano GB (eds). Neuropeptides and Immunoregulation. Springer-Verlag; 1994; 139-51.

4. Weigent DA, Blalock JE. Neuropeptides in bidirectional communication between the immune and neuroendocrine systems. In: Scharrer B, Smith EM, Stefano GB (eds). Neuropeptides and immunoregulation. Heidelberg: Springer-Verlag 1994; 14-27.

5. Stefano GB, Salzet M. Invertebrate opioid precursors: evolutionary conservation and the significance of enzymatic processing. Int Rev Cytol 1999; 187: 261-86.

6. Fricchione G, Zhu W, Cadet P, et al. Identification of endogenous morphine and a mu3-like opiate alkaloid receptor in human brain tissue taken from a patient with intractable complex partial epilepsy. Med Sci Monit 2008; 14: CS45-9.

7. Kream RM, Stefano GB. Homeopathic ethanol. Med Sci Monit 2008; 14: SC11-3.

8. Stefano GB, Kream RM, Mantione KJ, et al. Endogenous morphine/nitric oxide-coupled regulation of cellular physiology and gene expression: implications for cancer biology. Semin Cancer Biol 2008; 18: 199-210.

9. Stefano GB, Kream R. Endogenous opiates, opioids, and immune function: evolutionary brokerage of defensive behaviors. Semin Cancer Biol 2008; 18: 190-8.

10. Stefano GB, Scharrer B. Endogenous morphine and related opiates, a new class of chemical messengers. Adv Neuroimmunol 1994; 4: 57-68.

11. Stefano GB, Bilfinger TV, Fricchione GL. The immune neurolink and the macrophage: postcardiotomy delirium, HIV- 
associated dementia and psychiatry. Prog Neurobiol 1994; 42: 475-88.

12. Shipp MA, Stefano GB, Switzer SN, Griffin JD, Reinherz E. CD10 (CALLA)/neutral endopeptidase 24.11 modulates inflammatory peptide-induced changes in neutrophil morphology, migration, and adhesion proteins and is itself regulated by neutrophil activation. Blood 1991; 78: 1834-41.

13. Heagy W, Laurance M, Cohen E, Finberg RW. Neurohormones regulate T-cell function. J Exp Med 1990; 171: 1625-33.

14. Heagy W, Shipp MA, Finberg RW. Opioid receptor agonists and Ca2+ modulation in human B cell lines. J Immunol 1992; 149: 4074-81.

15. Heagy W, Duca K, Finberg RW. Enkephalins stimulate leukemia cell migration and surface expression of CD9. J Clin Invest 1995; 96: 1366-74.

16. Heagy W, Finberg RW, Teng E, et al. Opiate receptors and signalling in lymphocytes. Adv Exp Med Biol 1995.

17. Heagy W, Duca K, Finberg RW. Enkephalins stimulate leukemia cell migration and surface expression of CD9. J Clin Invest 1995; 96: 1366-74.

18. Sharp BM, Shahabi NA, Heagy $W$ et al. Dual signal transduction thorugh delta opioid receptors in a transfected human T-cell line. Proc Natl Acad Sci USA 1996; 93: 8294-9.

19. Stefano GB, Leung MK, Zhao X, Scharrer B. Evidence for the involvement of opioid neuropeptides in the adherence and migration of immunocompetent invertebrate hemocytes. Proc Natl Acad Sci USA 1989; 86: 626-30.

20. Stefano GB, Cadet P, Scharrer B. Stimulatory effects of opioid neuropeptides on locomotory activity and conformational changes in invertebrate and human immunocytes: Evidence for a subtype of delta receptor. Proc Natl Acad Sci USA 1989; 86: 6307-11.

21. Stefano GB. Role of opioid neuropeptides in immunoregulation. Prog Neurobiol 1989; 33: 149-59.

22. Falke NE, Fischer EG. Cell shape of polymorphonuclear leukocytes is influenced by opioids. Immunobiology 1985; 169: $532-9$

23. Falke NE, Fischer EG. Opiate receptor mediated internalization of 125I-beta-endorphin in human polymorphonuclear leukocytes. Cell Biol Int Rep 1986; 10: 429-37.

24. Fischer EG, Falke NE. The influence of endogenous opioid peptides on venous granulocytes. In: Plotnikoff NP, Faith RE, Murgo AJ, et al (eds). Enkephalins and endorphins: stress and the immune system. New York: Plenum Press 1986; 263-70.

25. Fischer EG, Stingl A, Kirkpatrick CJ. Opioid influence on the adherence of granulocytes to human umbilical vein endothelial cells in vitro. Cell Biol Intl Reports 1990; 14: 797-804.

26. Stefano GB, Melchiorri P, Negri L, Hughes TK Jr, Scharrer B. [D-Ala2]deltorphin I binding and pharmacological evidence for a special subtype of delta opioid receptor on human and invertebrate immune cells. Proc Natl Acad Sci U S A 1992; 89: 9316-20.

27. Jankovic BD, Maric D. Enkephalins as regulators of inflammatory immune reactions. In: Scharrer B, Smith EM, Stefano GB (eds). Neuropeptides and Immunoregulation. Berlin: Springer-Verlag 1994; 76-100.

28. Wybran J, Appelboom T, Famaey JP, Govaerts A. Suggestive evidence for receptors for morphine and methionineenkephalin on normal human blood T lymphocytes. J Immunol 1979; 123: 1068-70.
29. Stefano GB, Digenis A, Spector S, et al. Opiate-like substances in an invertebrate, an opiate receptor on invertebrate and human immunocytes, and a role in immunosuppression. Proc Natl Acad Sci USA 1993; 90: 11099-103.

30. Cadet P, Mantione KJ, Stefano GB. Molecular identification and functional expression of mu3, a novel alternatively spliced variant of the human mu opiate receptor gene. J Immunol 2003; 170: 5118-23.

31. Mantione KJ, Cadet P, Zhu W, et al. Endogenous morphine signaling via nitric oxide regulates the expression of CYP2D6 and COMT: autocrine/paracrine feedback inhibition. Addict Biol 2008; 13: 118-23.

32. Stefano GB, Stefano JM, Esch T. Anticipatory stress response: a significant commonality in stress, relaxation, pleasure and love responses. Med Sci Monit 2008; 14: RA17-21.

33. Stefano GB, Cadet P, Kream RM, Zhu W. The presence of endogenous morphine signaling in animals. Neurochem Res 2008; 33: 1933-9.

34. Zhu W, Esch T, Kream RM, Stefano GB. Converging cellular processes for substances of abuse: endogenous morphine. Neuro Endocrinol Lett 2008; 29: 63-6.

35. Kream RM, Stefano GB. Endogenous morphine and nitric oxide coupled regulation of mitochondrial processes. Med Sci Monit 2009; 15: RA263-8.

36. Stefano GB, Esch T, Kream RM. Xenobiotic perturbation of endogenous morphine signaling: paradoxical opiate hyperalgesia. Med Sci Monit 2009; 15: RA107-10.

37. Stefano GB, Kream RM, Esch T. Revisiting tolerance from the endogenous morphine perspective. Med Sci Monit 2009; 15: RA189-98.

38. Zhu W, Mantione KJ, Shen L, et al. Tyrosine and tyramine increase endogenous ganglionic morphine and dopamine levels in vitro and in vivo: CYP2D6 and tyrosine hydroxylase modulation demonstrates a dopamine coupling. Med Sci Monit 2005; 11: BR397-404.

39. Zhu W, Cadet P, Baggerman G, Mantione KJ, Stefano GB. Human white blood cells synthesize morphine: CYP2D6 modulation. J Immunol 2005; 175: 7357-62.

40. Atmanene C, Laux A, Glattard E, et al. Characterization of human and bovine phosphatidylethanolamine-binding protein (PEBP/RKIP) interactions with morphine and morphine-glucuronides determined by noncovalent mass spectrometry. Med Sci Monit 2009; 15: BR178-87.

41. Stefano GB, Salzet M, Ottaviani E. Neuroimmune chemical messengers and their conservation during evolution. In: Rinkevich B, Matranga V (eds). Stem Cells in Marine Organisms. Springer 2009; 139-64.

42. Stefano GB, Kream RM. Dopamine, morphine, and nitric oxide: an evolutionary signaling triad. CNS Neurosci Ther 2010; 16: e125-37.

43. Kream RM, Mantione KJ, Sheehan M, Stefano GB. Morphine's chemical messenger status in animals. Activitas Nervosa Superior Rediviva 2009; 51: 153-61.

44. Zhu W, Stefano GB. Comparative aspects of endogenous morphine synthesis and signaling in animals. Ann N Y Acad Sci 2009; 1163: 330-9.

45. Casares FM, Mantione KJ, Kream RM, Stefano GB. Neurotransmitter gene microarray analysis in human white blood cells and human stem cells following morphine exposure. Activitas Nervosa Superior Rediviva 2010; 51: 153-8.

46. Esch T, Stefano GB. The neurobiology of stress management. Neuro Endocrinol Lett 2010; 31: 30.

47. Mantione K, Kream RM, Stefano GB. Variations in critical morphine biosynthesis genes and their potential to 
influence human health. REVIEW. Neuro Endocrinol Lett 2010; 31: 9.

48. Mantione KJ, Sheehan M, Gerber S, et al. Microarray validation of vertebrate biogenic amine and acetylcholine signaling in invertebrates. Biogenic Amines 2010; in press.

49. Mantione KJ, Zhu W, Kream RM, Esch T, Stefano GB. Regulation of the transcription of the catechol-Omethyltransferase gene by morphine and epinephrine. Activitas Nervosa Superior Rediviva 2010; in press.

50. Cadet P, Mantione KJ, Zhu W, Kream RM, Sheehan M, Stefano GB. A functionally coupled mu3-like opiate receptor/nitric oxide regulatory pathway in human multilineage progenitor cells. J Immunol 2007; 179: 5839-44.

51. Dobrenis K, Makman MH, Stefano GB. Occurrence of the opiate alkaloid-selective $\mathrm{m} 3$ receptor in mammalian microglia, astrocytes and kupffer cells. Brain Res 1995; 686: 239-48.

52. Makman MH, Bilfinger TV, Stefano GB. Human granulocytes contain an opiate receptor mediating inhibition of cytokine-induced activation and chemotaxis. J Immunol 1995; 154: 1323-30.

53. Makman MH, Dvorkin B, Stefano GB. Murine macrophage cell lines contain m3-opiate receptors. Eur J Pharmacol 1995; 273: R5-6.

54. Kream RM, Sheehan M, Cadet P, et al. Persistence of evolutionary memory: primordial six-transmembrane helical domain mu opiate receptors selectively linked to endogenous morphine signaling. Med Sci Monit 2007 13: SC5-6.

55. Evans CJ, Keith DE Jr, Morrison H, Magendzo K, Edwards $\mathrm{RH}$. Cloning of a delta opioid receptor by functional expression. Science 1992; 258: 1952-5.

56. Kieffer BL, Befort K, Gaveriaux-Ruff CE, Hirth CG. The dopioid receptor: isolation of a cDNA by expression cloning and pharmacological characterization. Proc Natl Acad Sci USA 1992; 89: 12048-52.

57. Yasuda K, Raynor K, Kong H, et al. Cloning and functional comparison of $k$ and $d$-opioid receptors from mouse brain. Proc Natl Acad Sci USA 1993; 90: 6736-40.

58. Hakusui S, Yasuda T, Yanagi T, et al. A radiological analysis of heart sympathetic functions with meta-[1231]iodobenzylguanidine in neurological patients with autonomic failure. J Aut Nerv Sys 1994; 49: 81-4.

59. Jankovic BD, Radulovic J. Quaternary naltrexone: its immunomodulatory activity and interaction with brain delat and kappa opioid receptors. Immunopharmacology 1994; 28: 105-12.

60. Duvaux-Miret O, Stefano GB, Smith EM, Dissous C, Capron $\mathrm{A}$. Immunosuppression in the definitive and intermediate hosts of the human parasite Schistosoma mansoni by release of immunoactive neuropeptides. Proc Natl Acad Sci USA 1992; 89: 778-81.

61. Duvaux-Miret O, Stefano GB, Smith EM, Mallozzi L, Capron A. Proopiomelanocortin-derived peptides as tools of immune evasion for the human trematode Schistosoma mansoni. Acta Biol Hungari 1992; 43: 281-6.

62. Duvaux-Miret O, Stefano GB, Smith EM, Capron A. Neuroimmunology of host parasite interactions: proopiomelanocortin derivedpeptides in the infection by Schistosoma mansoni. Adv Neuroimmunol 1992; 2: 297-311.

63. Duvaux-Miret O, Capron A. Proopiomelanocortin in the helminth Schistosoma mansoni. Synthesis of bendorphin, ACTH and a-MSH. Existence of POMC-related sequences. Ann N Y Acad Sci 1992; 650: 245-50.

64. Poole S, Bristow AF, Lorenzetti BB, Das RE, Smith TW, Ferreira SH. Peripheral analgesic activities of peptides related to alpha- melanocyte stimulating hormone and interleukin-1 beta 193-195. Br J Pharmacol 1992; 106: 489-92.
65. Smith EM, Hughes TK, Hashemi F, Stefano GB. Immunosuppressive effects of ACTH and MSH and their possible significance in human immunodeficiency virus infection. Proc Natl Acad Sci USA 1992; 89: 782-6.

66. Smith EM, Hughes TK, Cadet P, Stefano GB. CRF induced immunosuppression in human and invertebrate immunocytes. Cell Mol Neurobiol 1992; 12: 473-82.

67. Kream RM, Stefano GB. De novo biosynthesis of morphine in animal cells: an evidence-based model. Med Sci Monit 2006; 12: RA207-19.

68. Zhu W, Cadet P, Mantione KJ, Kream RM, Stefano GB. Response to comment on "Human white blood cells synthesize morphine: CYP2D6 modulation". J Immunol 2006; 176: 5704

69. Castardeli E, Duarte DR, Minicucci MF, et al. Exposure time and ventricular remodeling induced by tobacco smoke exposure in rats. Med Sci Monit 2008; 14: BR62-6.

70. Tanii H, Higashi T, Nishimura F, Higuchi Y, Saijoh K. Effects of cruciferous allyl nitrile on phase 2 antioxidant and detoxification enzymes. Med Sci Monit 2008; 14: BR189-92.

71. Zhu W. CYP2D6: a key enzyme in morphine synthesis in animals. Med Sci Monit 2008; 14: SC15-8.

72. Gu Y, Yun L, Tian Y, Hu Z. Association between COMT gene and Chinese male schizophrenic patients with violent behavior. Med Sci Monit 2009; 15: CR484-9.

73. Naha N, Lee HY, Naser MI, Park TJ, Kim SH, Kim MO. Ethanol inhibited apoptosis-related RNA binding protein, Napor-3 gene expression in the prenatal rat brain. Med Sci Monit 2009; 15: BR6-12.

74. Zhu W, Mantione KJ, Casares FM, et al. Alcohol-, nicotine, and cocaine-evoked release of morphine from invertebrate ganglia: Model system for screening drugs of abuse. Med Sci Monit 2006; 12: BR155-61.

75. Zhu W, Mantione KJ, Shen L, Lee B, Stefano GB. Norlaudanosoline and nicotine increase endogenous ganglionic morphine levels: Nicotine addiction. Cell Mol Neurobiol 2006; 26: 1037-45.

76. Zhu W, Mantione K, Kream RM, Stefano GB. Alcohol-, nicotine-, and cocaine-evoked release of morphine from human white blood cells: substances of abuse actions converge on endogenous morphine release. Med Sci Monit 2006; 12: BR350-4. 